\title{
Halides as versatile anions in asymmetric anion-binding organocatalysis
}

\author{
Lukas Schifferer, Martin Stinglhamer, Kirandeep Kaur and Olga García Macheño*
}

Review

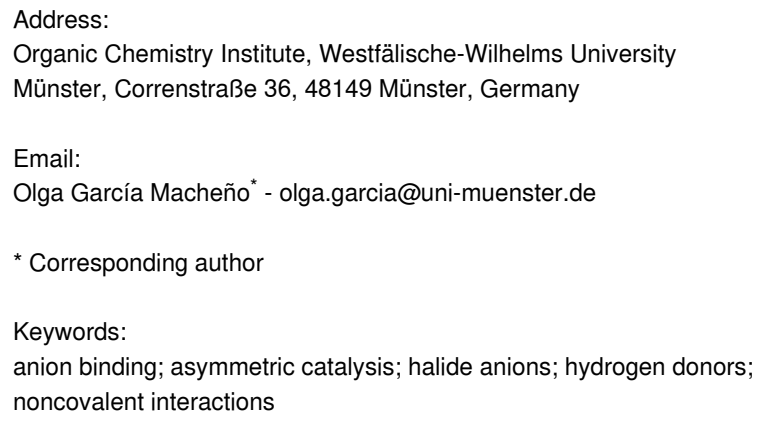

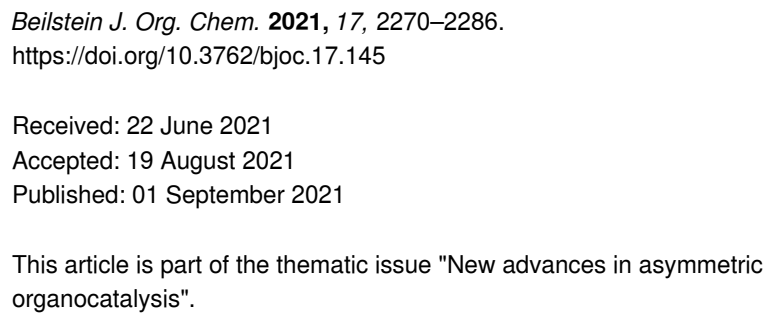

(C) 2021 Schifferer et al.; licensee Beilstein-Institut. License and terms: see end of document.

\begin{abstract}
This review intends to provide an overview on the role of halide anions in the development of the research area of asymmetric anion-binding organocatalysis. Key early elucidation studies with chloride as counter-anion confirmed this type of alternative activation, which was then exploited in several processes and contributed to the advance and consolidation of anion-binding catalysis as a field. Thus, the use of the halide in the catalyst-anion complex as both a mere counter-anion spectator or an active nucleophile has been depicted, along with the new trends toward additional noncovalent contacts within the HB-donor catalyst and supramolecular interactions to both the anion and the cationic reactive species.
\end{abstract}

\section{Introduction}

Halogens and the respective anionic halides occupy an essential role in natural and chemical processes [1-4]. While in chemical syntheses halogens are often regarded as surrogates for further functionalization, their role in natural and physiological processes is much more diverse. One of these processes is the ability of large complex molecules and enzymes to recognize halide anions via hydrogen bonds in aqueous media [5]. Amongst others, the regulation of membrane potentials is one of such applications, in which the transport of chloride anions is facilitated by noncovalent hydrogen bonding interactions (Figure 1a) [6]. Noncovalent interactions are in fact one of the essential factors for the molecular recognition in enzymatic reactions, especially anionic species [7]. Even though initial reports of nonenzymatic halide recognition date back to the 1960s [8], strategies to exploit this ability for synthetic or catalytic purposes were vastly disregarded in the following decades [9]. This relies on the fact that it is highly challenging to design small molecule catalysts that resemble anion-binding properties of enzymes. Hence, a major challenge of small organic receptors to mimic nature's capability of binding to the targeted anions resides in the supramolecular properties of enzymes and co-factors to form exact matching binding cavities. In this context, halides offer an advantage over various other anionic species because their spherical topology reduces the number of 
possible isomers or complexes upon interaction with the receptor. As a consequence, predictable cavity sizes based on the employed halide allows for easier targeting of the small receptor molecule and, thus, reducing the need for complexity compared to enzymes or co-factors. Conversely, a multitude of geometries may need to be considered for anions with linear, coplanar, trigonal or tetrahedral topologies (Figure 1b) $[5,10]$.

a)

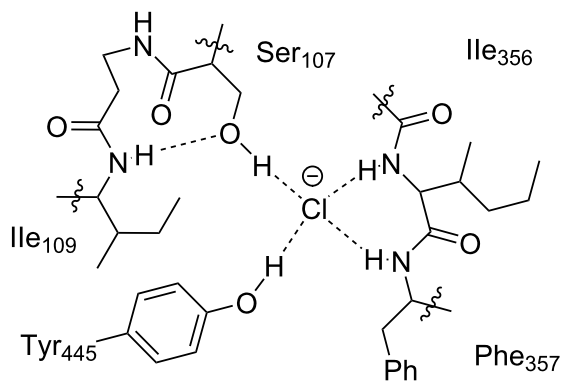

b)<smiles></smiles><smiles>C=[N+]1[CH]CCCC1</smiles><smiles>O=[N+]([O-])O[C@H]1CCCC[C@@H]1O</smiles><smiles>C[PH]1(C)OCCCCCO1</smiles>
RO'朩OR

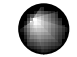

spherical

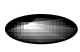

planar

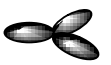

trigonal

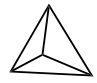

tetrahedral
Figure 1: a) Binding interactions in the chloride channel of $E$. coli. and b) examples of chloride, cyanide, nitrate and phosphate anions with their respective topology.

However, following the advances in anion coordination and supramolecular chemistry [7-11], this field of research has attracted more attention within the past two decades. Immense efforts were made to identify small molecules that are able to productively bind anions via noncovalent hydrogen bonding, from which cationic receptors have often proven more efficient
$[9,12]$. A breakthrough in the field of anion binding towards its application in catalysis was achieved with the findings that neutral (thio)urea derivatives are potent anion receptors due to their ability to bind anions of various topologies, including the spherical halides [10]. The key to hydrogen bonding of the halide anion resides in the polarized $\mathrm{N}-\mathrm{H}$ bonds of these (thio)urea units, which have since served as a benchmark in the design and development of anion receptor catalysts [12-14]. Consequently, other synthetic anion receptors have been developed in the past decades, all based on polarized hydrogen bond motifs. While commonly based on $\mathrm{N}-\mathrm{H}$ bonds [15-18], also polarized $\mathrm{O}-\mathrm{H}[19,20]$ and even $\mathrm{C}-\mathrm{H}[21,22]$ bond-based systems have been realized. As a consequence of the importance and increasing attention of this field, there are already a few reviews on anion-binding catalysis implying different types of anions [10,15,23-29]. However, in this review, we aim at providing an overview of the evolution of anion-binding catalysis by focusing on the key role of halides as decisive anions for the development of the concepts and implementation of natural principles of anion recognition by small molecule catalysts.

\section{Review}

\section{Hydrogen bonding to neutral substrates or anion binding?}

In the early stages of anion-binding-catalysis development, some reactions might have potentially been mistaken to be hydrogen-bond catalyzed [15,23]. While both catalyses are closely related by making use of hydrogen-bond interactions as the directing noncovalent force, they can be distinguished by the type of substrate that is bound to and activated by the catalyst (Figure 2a). In H-bond catalysis, neutral substrates such as carbonyl compounds are coordinated to the H-bond catalyst, whereas anion-binding catalysis relies on the formation of an ion pair by binding to the counter-anion of an ionic substrate. The ionization of the corresponding substrate can either occur before the coordination to the anion or the catalyst itself directly participates in the ionization step by an anion abstraction-type a) $\mathrm{H}$-bond vs anion-binding catalysis

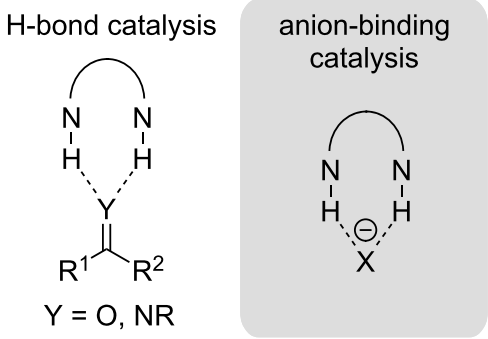

b) anion-binding activation modes

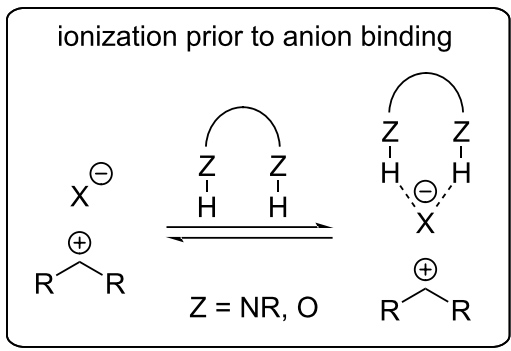

active participation in bond cleavage

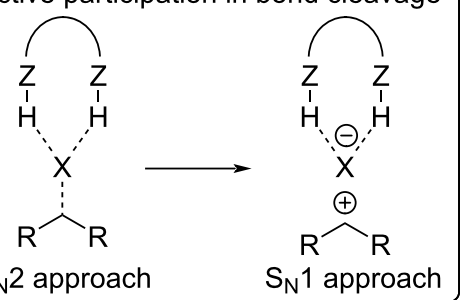

Figure 2: a) H-bond vs anion-binding catalysis and b) activation modes in anion-binding catalysis. 
process (Figure $2 \mathrm{~b}$ ). In the latter approach, the $\mathrm{C}-\mathrm{X}$ bond cleavage can then either follow a $\mathrm{S}_{\mathrm{N}} 1$ or $\mathrm{S}_{\mathrm{N}} 2$ pathway.

For enantioselective purposes, solvation of the ion pair is crucial for obtaining high stereoinduction. While more polar solvents give solvent-separated or solvent-shared ion pairs - in which the components have their own solvent shells -, nonpolar solvents are more likely to lead to contact-ion pairs. As such, the cation and anion are in closer proximity as one solvent shell is shared. If a chiral catalyst binds then to the anion, a chiral contact-ion pair can be formed, which is necessary for the transfer of the chiral information to the product. As a consequence, most of the reported methods embracing enantioselective anion-binding catalysis rely on the use of nonpolar solvents such as ethers or aromatic compounds.

\section{Pioneering work}

The concept of anion-binding catalysis was first penned by Schreiner et al. in 2006, who realized the acetalization of benzaldehyde (1) with a thiourea catalyst (3, Scheme 1) [30,31] They proposed the reaction to proceed via thiourea-catalyzed orthoester hydrolysis, leading to the formation of a catalystbound alkoxide species $(\mathbf{3} \cdot \mathrm{OEt})$ that is then able to attack the benzaldehyde for product 2 formation.

However, it took some time until the scientific community started considering and taken cognizance of the potential of this type of activation mode in catalysis. In this regard, Jacobsen

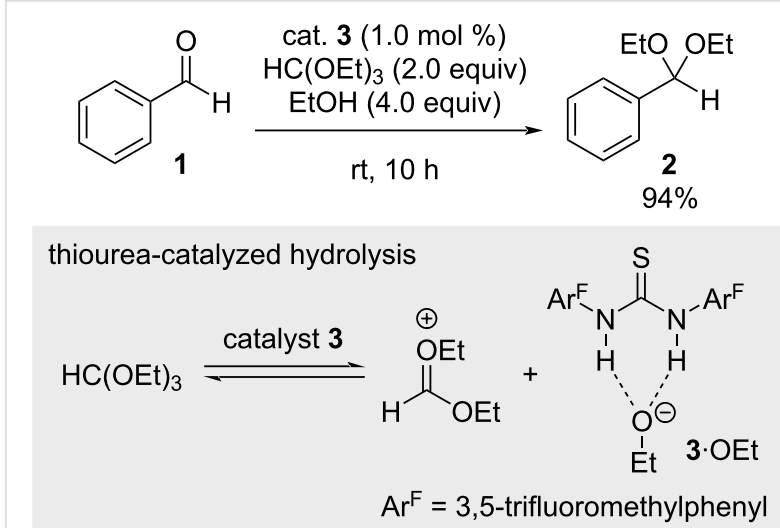

Scheme 1: First proposed anion-binding mechanism in the thioureacatalyzed acetalization of benzaldehyde.

and co-workers reported in 2004 an asymmetric Pictet-Spengler reaction of tryptamine-derived imines $\mathbf{4}$ in the presence of acetyl chloride and 2,6-lutidine, where the chiral thiourea catalyst 6 was employed to enable good yields and enantioselectivities (Scheme 2a) [32]. The initial motivation of their first studies revolved around hydrogen bond donor catalysts and their application in $\mathrm{N}$-acyliminium ion reactions. At this point, the mechanistic proposal, albeit speculative, was based on the hypothesis that neutral chloroamide structures I were the reactive intermediates in the reaction. Under this premise, H-bonding to the carbonyl group was proposed as the binding mode of the catalyst and the reaction to proceed via a $\mathrm{S}_{\mathrm{N}} 2$-type mecha-

a)

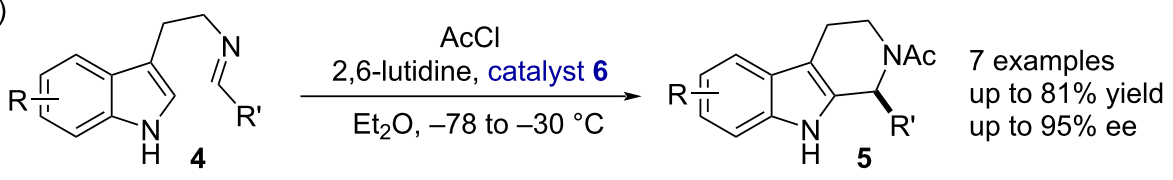

b)
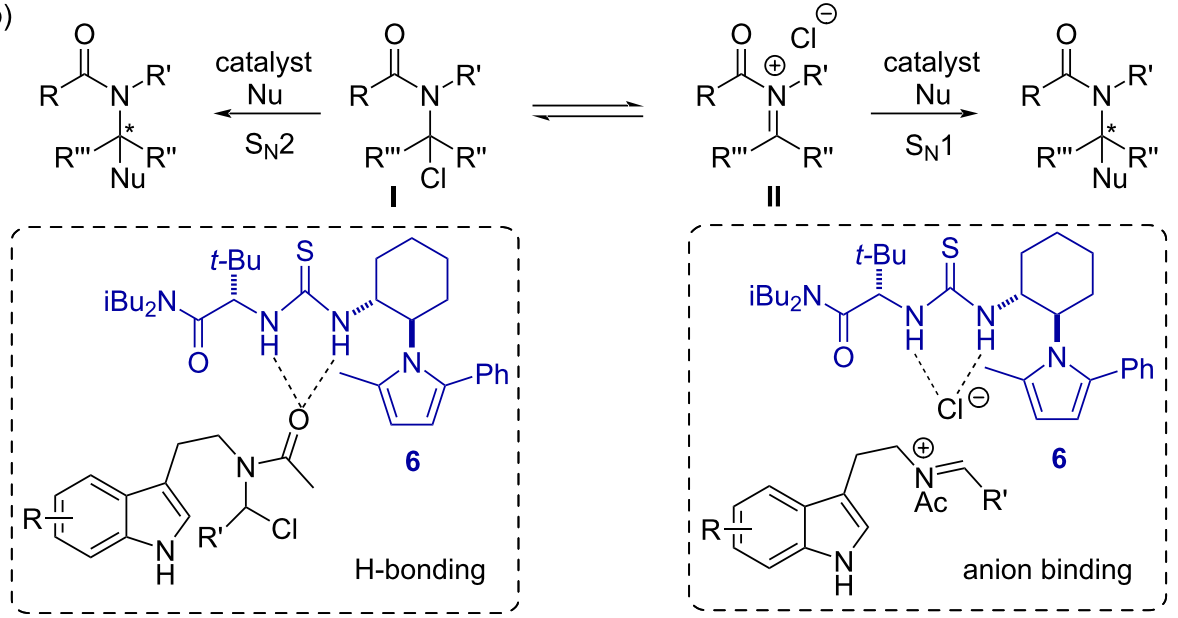

Scheme 2: a) Thiourea-catalyzed enantioselective acyl-Pictet-Spengler reaction of tryptamine-derived imines 4. b) Equilibrium between the ionic $\left(\mathrm{S}_{\mathrm{N}} 1\right.$-type mechanism) and neutral form $\left(\mathrm{S}_{\mathrm{N}} 2\right.$-type reaction). The key intermediates for the respective binding modes are displayed in the boxes. 
nism (Scheme 2b, left). Not considered at that time was the anion-binding pathway through the iminium chloride salt II, which would proceed via a $S_{N} 1$-type mechanism (Scheme $2 b$, right).

However, based on the freshly coined concept of anion-binding activation [30,31] and as the exact interaction mode of the catalyst remained elusive, Jacobsen's group focused their attention towards mechanistic studies of thiourea-catalyzed reactions. In 2007, they reported a Pictet-Spengler cyclization reaction of succinimide and glutarimide-derived hydroxylactams 7 (Scheme 3) [33]. This system was designed in a way that key experimental observations could be made to analyze whether a $\mathrm{S}_{\mathrm{N}} 1$ or $\mathrm{S}_{\mathrm{N}}$ 2-type mechanism takes place. A strong dependence of the enantioselectivity on the counterion and solvent was observed and, therefore, a $S_{\mathrm{N}} 1$-type mechanism was concluded. Furthermore, their studies proved that an ion pair is required for the reaction to proceed and, most importantly, that the thiourea catalyst 9 interacts with the chloride of the $N$-acyliminium ion as opposed to the carbonyl group.

Based on this concept, the applicability of $\mathrm{N}$-acyliminium chlorides in thiourea-catalyzed anion-binding reactions was further explored. In 2008, an intramolecular asymmetric Pictet-Spengler-type cyclization reaction with pyrrole derivatives $\mathbf{1 3}$ was reported. The authors were not only able to control the enantioselectivity, but this system also allowed the control over regio- selectivity ( $\mathrm{C} 2$ vs $\mathrm{C} 4$ cyclization) through alteration of the $\mathrm{N}$-substituent of the pyrrole substrate and the acylating reagent (Scheme 4a) [34]. This example showcases that next to the counterion, the acylating group can have a major influence on these types of reactions. The first thiourea-catalyzed asymmetric intermolecular reaction with $\mathrm{N}$-acyliminium chlorides was then also realized by the same group in 2009. Therein, nucleophilic addition of indoles $\mathbf{1 7}$ to the $\mathrm{N}$-acyliminium chlorides was achieved with excellent enantiomeric excess (Scheme 4b) [35].

During this early period, the group of Jacobsen also reported an asymmetric thiourea-catalyzed Reissert reaction of isoquinolines 21 (Scheme 5a) [36]. The mechanism proceeds by initial activation of the isoquinoline via $N$-acylation and subsequent dearomatization by a nucleophilic attack in the $\mathrm{C} 1$ position. Analogously to the Pictet-Spengler cyclization, the group initially speculated that the thiourea catalyst 6 interacts with the carbonyl function of the amide intermediate $\mathbf{I}$ and, thus, a $\mathrm{S}_{\mathrm{N}} 2$ type mechanism via hydrogen bonding catalysis was proposed. A similar bidentate carbonyl activation proposal was later on reported from the Takemoto group in 2007, where the less reactive quinoline derivatives $\mathbf{2 3}$ were employed in a thiourea-catalyzed Reissert reaction (Scheme 5b) [37]. In both cases, however, the binding mode of the catalyst can rather be described by the formation of a close ion pair with the chloride of the $N$-acyl(iso)quinolinium intermediate II. Hence, the reaction

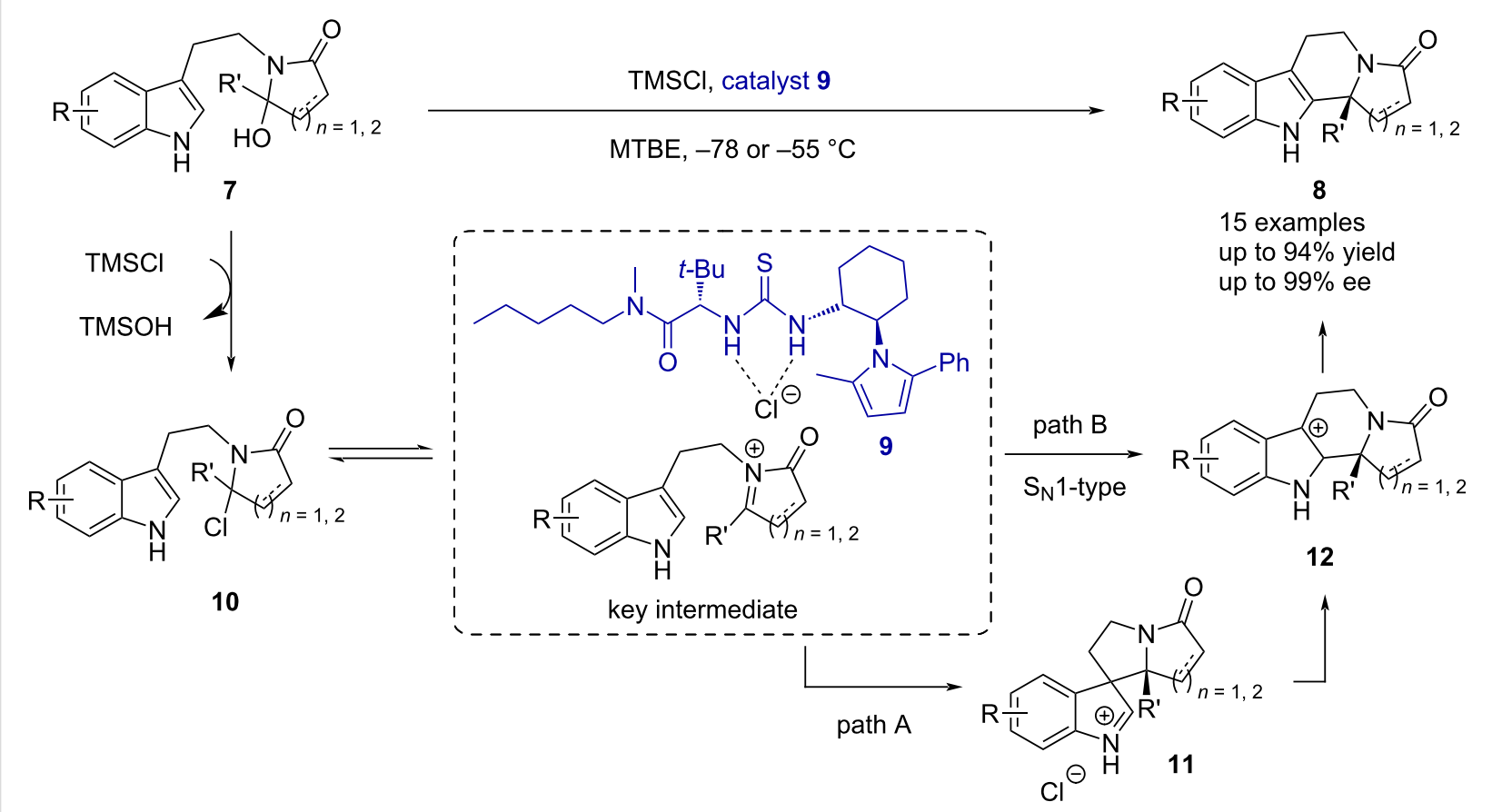

Scheme 3: Proposed mechanism of the thiourea-catalyzed enantioselective Pictet-Spengler reaction of hydroxylactams 7. First provided evidence of anion binding instead of carbonyl hydrogen bonding. 


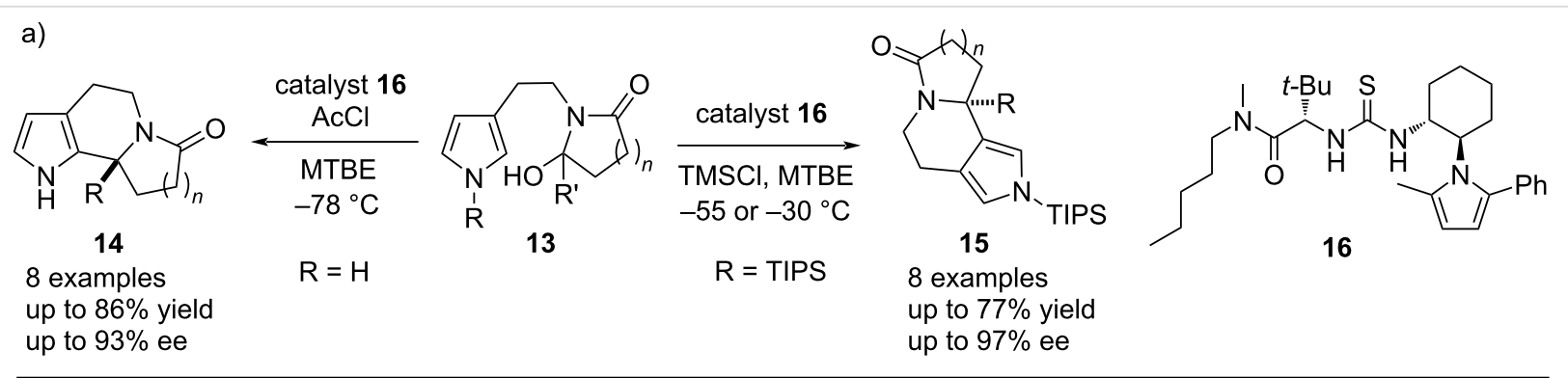

b)<smiles>[R]#Cc1cc[nH]c1</smiles>

17<smiles>O=C1CCC(O)N1Cc1ccccc1</smiles>

18

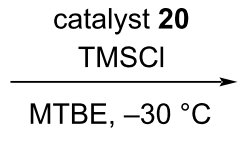

\section{$\mathrm{R}$}<smiles></smiles>

19<smiles>CCOc1cc(C(C)(C)C)cc(/C=N/[C@H]2CCCC[C@H]2NC(=S)N[C@@H](Cc2ccccc2)C(=O)N2CCC[C@H]2c2ccccc2)c1O</smiles>

up to $93 \%$ yield up to $95 \%$ ee

Scheme 4: a) Thiourea-catalyzed intramolecular Pictet-Spengler-type cyclization of hydroxylactam-derived $N$-acyliminium chlorides and b) thioureacatalyzed intermolecular hydroxy lactam-derived $\mathrm{N}$-acyliminium chlorides with indoles.

a)<smiles>[R]c1cccc2cnccc12</smiles>

1) $\mathrm{TrocCl}$<smiles>CCOCCOCC</smiles>

21<smiles>CC(C)O[SbH2]</smiles><smiles>[R]c1cccc2c1C=C[NH+]([O+])[C@H]2CC(=O)OC(C)C</smiles>

8 examples up to $86 \%$ yield up to $92 \%$ ee
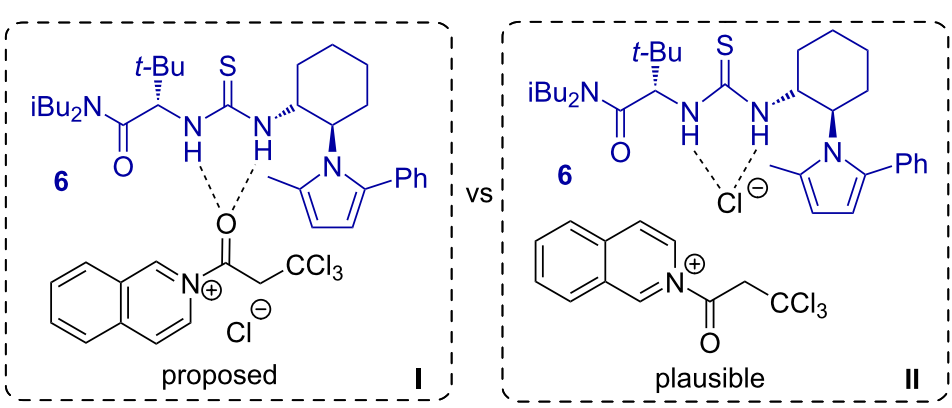

b)<smiles>[R]c1cccc2ncccc12</smiles>

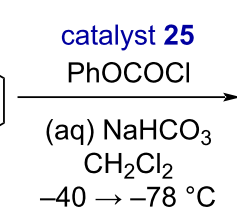

23<smiles>[Ga]C=C[Bi]</smiles><smiles>O=C(c1ccccc1)N1c2ccccc2C=CC1/C=C/[Ba]</smiles>

24

10 examples up to $78 \%$ yield up to $97 \%$ ee

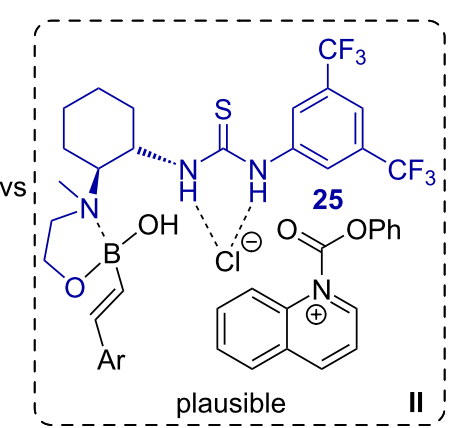

Scheme 5: Enantioselective Reissert-type reactions of a) (iso)quinolines with silyl ketene acetals, and b) vinylboronic acids.

would follow a $\mathrm{S}_{\mathrm{N}} 1$-type mechanism via anion-binding catalysis. In Jacobsen's report, the acylating agent 2,2,2-trichloroethyl chloroformate (TrocCl) and nucleophilic silyl ketene acetals were employed to obtain the dihydroisoquinolines 22 in good yields and enantioselectivities up to $92 \%$ ee. The Takemoto group with their system also achieved yields up to $78 \%$ and en- antioselectivities up to $97 \%$ ee, using phenyl chloroformate as the acylating reagent and vinylboronic acids as the nucleophiles in the presence of sodium bicarbonate.

The key finding of anion-binding activation opened up a whole new field for asymmetric transformations. Thus, many asym- 
metric transformations relying on this type of activation mode were subsequently developed [15,23-29]. It is worthy to be mentioned, that Reissert dearomatizations of $N$-heteroarenes, especially of isoquinolines [36], and nucleophilic addition to 1-chloroisochromanes [38] have become benchmark reactions in the context of anion-binding catalysis. Besides reports of thiourea-catalyzed reactions with different nucleophiles [39,40], the focus has also been turned to the development of other catalyst systems that are not based on $\mathrm{N}-\mathrm{H}$ bonds, such as the chiral silanediol catalysts first reported by Mattson and co-workers in $2013[19,20]$. Furthermore, it is worthy to mention that in parallel to the investigations towards new chiral catalysts and asymmetric methodologies, a few innovative nonchiral alternative H-donor or halide-binding organocatalysts, like, e.g., tridentate phosphoramides [41], onium salts [42] such as Berkessel's pyridinium systems [43], or Huber's bis-iodo imidazolium [44] and neutral bridged 2,6-diiodo-3,4,5-trifluorophenyl-type catalysts [45]. Additionally, the first asymmetric systems involving purely halogen bond donor catalysis have recently been developed by the groups of Huber [46] and García Mancheño [47]. Moreover, though chloride as halide counteranion still being particularly prominent, the application of anion-binding catalysis has been successfully demonstrated for other halogens, and different types of substrates such as the benzhydryl cation [48-51].

\section{Halides as counter-anions vs nucleophiles}

The latest advances in anion-binding catalysis not only allowed for excellent translation of stereochemical information, but also delivered an insight into the mechanism of the anion-binding process. However, the counter-anion involved, and more precisely the halide anion itself, has remained a mere spectator in the developed catalyses (Figure 3a). Nevertheless, recent reports showed that the bound halide anions can also engage as the nucleophile, which has been exploited in ring opening and related reactions (Figure 3b).
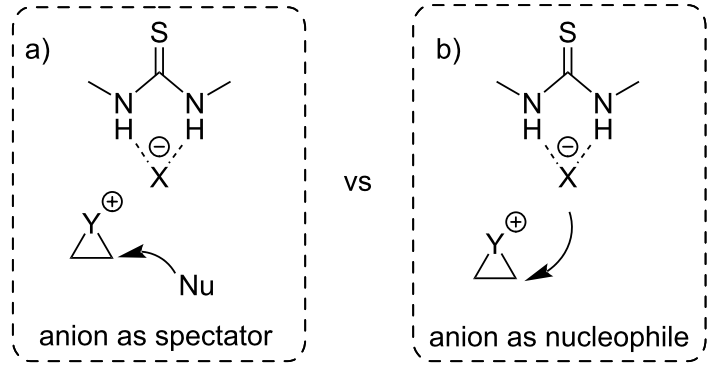

Figure 3: Role of the counter-anion: a) Anion acting as a spectator and b) anion participating directly as the nucleophile.

In general, the idea of enantioselective ring opening produces two fixed stereocenters during one synthetic operation, increas- ing the complexity of the product significantly. This makes asymmetric ring-opening reactions a powerful tool for the synthesis of highly complex target molecules. With this concept in mind, anion-binding catalysis has successfully been employed for asymmetric ring-opening reactions, implying halide anions as both mere counter-anions in the ion-pair complex or active nucleophiles.

In 2014, Jacobsen et al. developed a highly enantioselective selenocyclization reaction of olefins $\mathbf{2 6}$, using the chiral squaramide 28 as a dual hydrogen bond donor (Scheme 6) [16]. Although early-stage enantio-enrichment during the introduction of selenium is hard to maintain due to the conformational lability of the seleniranium ion [52-54], this initial problem can be exploited through the addition of an anion-binding catalyst. In this way, the configurational scrambling is used for a dynamic kinetic resolution during the intramolecular nucleophilic opening of the seleniranium ring. Through favorable cation $-\pi$ interactions with the catalyst, the $(S, S)$-intermediate reacts faster than its opposing enantiomer, allowing for excellent yields up to $95 \%$ and high enantioselectivities up to $91 \%$ ee.

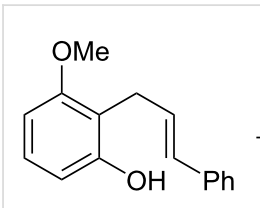

26

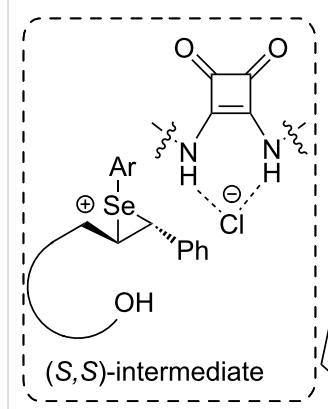

catalyst 28 NPSS, $\mathrm{HCl}$

$\mathrm{HMPA}(\mathrm{S})$ toluene, $-35^{\circ} \mathrm{C}$

14 examples up to $95 \%$ yield up to $91 \%$ ee
Scheme 6: Enantioselective selenocyclization catalyzed by squaramide 28 .

In contrast to the previous example, in which the chloride anion was only a spectator linking the substrate and catalyst in the presence of an external nucleophile, halides can also be tuned to participate as the nucleophile in certain reactions. In theory, the close association of the catalyst and the anionic nucleophile might allow for better stereocontrol. An early example utilizing this strategy was provided by Jacobsen and co-workers for the desymmetrization of meso-aziridines 29. In their work, the bifunctional phosphinothiourea catalyst $\mathbf{3 1}$ promoted the $\mathrm{C}-\mathrm{N}$ 
bond cleavage by hydrochloric acid upon initial protonation (Scheme 7) [55]. Subsequently, the catalyst-bound chloride anion performs a $\mathrm{S}_{\mathrm{N}}$ 2-type attack on the coordinated benzoylprotected aziridine, which leads to a formal addition of $\mathrm{HCl}$.<smiles>[R16]C1C2CCCCC12</smiles>

29

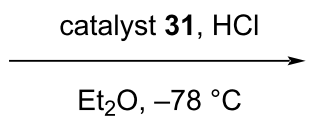

$\mathrm{Et}_{2} \mathrm{O},-78^{\circ} \mathrm{C}$

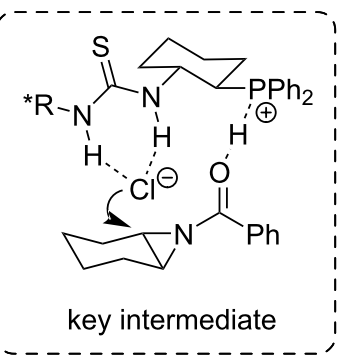

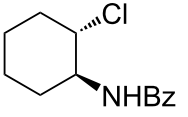

30

7 examples up to $99 \%$ yield up to $92 \%$ ee
Scheme 7: Desymmetrization of meso-aziridines catalyzed by bifunctional thiourea catalyst 31 .
This concept was further developed and successfully employed by Ooi in the desymmetrization of meso-aziridines $\mathbf{3 2}$ with TMSX as chloride and bromide with similar performances as nucleophile precursors using a triazolium-amide chiral catalyst 34 [21] (Scheme 8a), as well as by Jacobsen in the desymmetrization of oxetanes $\mathbf{3 5}$ using TMSBr and squaramide $\mathbf{3 7}$ as catalyst [56] (Scheme 8b). For the latter, a more detailed mechanistic study was recently provided [57]. The existence of two competing Brønsted acid and Lewis acid mechanistic pathways leading to the same product with high enantioselectivity was then uncovered. Jacobsen et al. reasoned that the key for this highly selective transformation lies in attractive cation- $\pi$ and cation-dipole secondary interactions between the catalyst and the substrate, which exclusively stabilize the transition state that forms the major enantiomer.

Furthermore, Gouverneur and co-workers established an enantioselective nucleophilic fluorination protocol using a chiral bisurea catalyst 41 and $\mathrm{CsF}$ as an inorganic fluoride source (Scheme 9a) [18]. By employing in situ-generated meso-episulfonium ions, they were able to synthesize $\beta$-fluorosulfides $\mathbf{3 9}$ in a)<smiles>[R]C1C([R])N1S(=O)(=O)O[Na]</smiles>

32

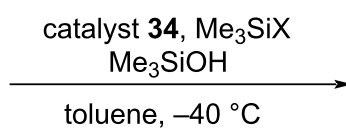

toluene, $-40^{\circ} \mathrm{C}$<smiles>[R]C([X])[C@H]([R])NS(=O)(=O)O[Na]</smiles>

33
7 examples up to $99 \%$ yield up to $97 \%$ ee

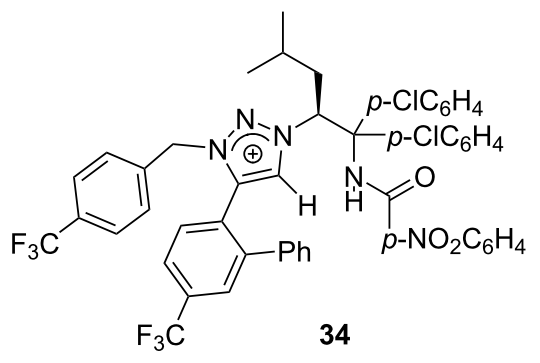

b)<smiles>[R]C1([R])COC1</smiles>

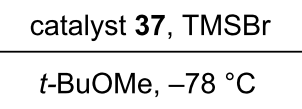

35<smiles>[R]C([R])(CBr)CO[Na]</smiles>

36

22 examples up to $>99 \%$ yield up to $99 \%$ ee<smiles>CC(C)(C)[C@H](Nc1c(Nc2cc(C(F)(F)F)cc(C(F)(F)F)c2)c(=O)c1=O)C(=O)N1CCC[C@]1(C)c1cc2ccccc2c2ccccc12</smiles>

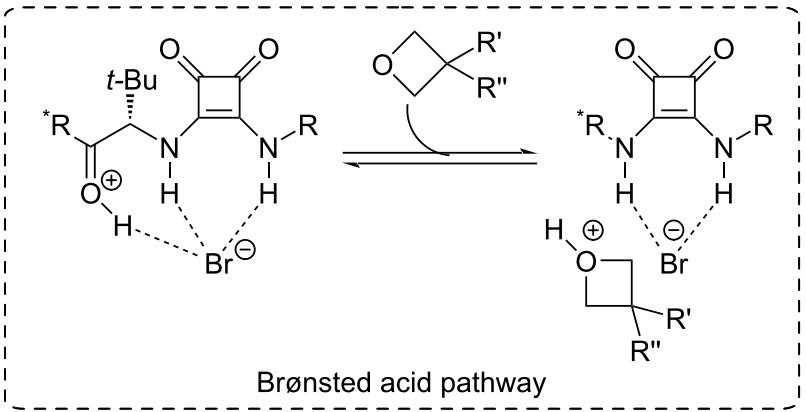

vs

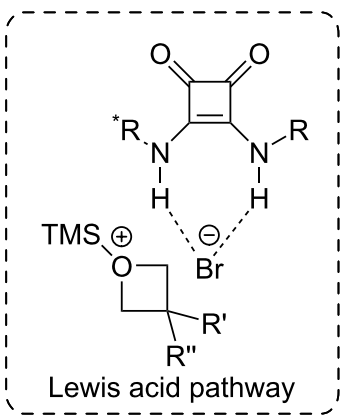

Scheme 8: Anion-binding-catalyzed desymmetrization of a) meso-aziridines catalyzed by chiral triazolium catalyst $\mathbf{3 4}$ by Ooi et al., and b) oxetans catalyzed by chiral squaramide 37 by Jacobsen et al. 
a)<smiles>[R]S[C@H](c1ccccc1)[C@@H](F)c1[R]cccc1</smiles>

39

12 examples up to $98 \%$ yield up to $94 \%$ ee

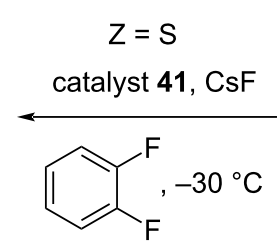

b)<smiles>[R][Z]C([R])C([R])[X]</smiles>

38

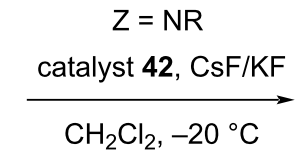

$\mathrm{X}=\mathrm{Cl}$ or $\mathrm{Br}$

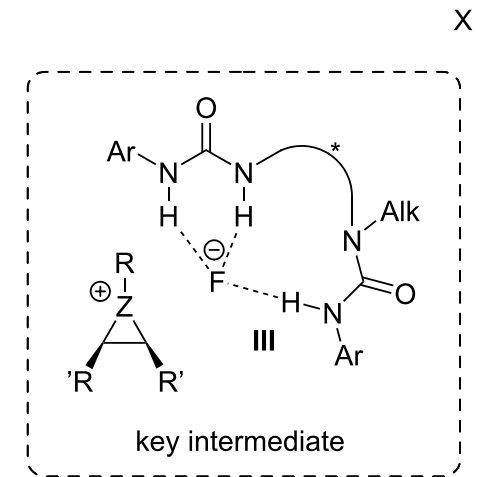<smiles>[R]Nc1ccc2ccccc2c1-c1c(NC(=O)Nc2cc(C(F)(F)F)cc(C(F)(F)F)c2)ccc2ccccc12</smiles><smiles>[R]C(F)[C@H]([R])N([R])[R]</smiles>

40

22 examples up to $95 \%$ yield up to $95 \%$ ee

Scheme 9: Bis-urea-catalyzed enantioselective fluorination of a) $\beta$-bromosulfides and b) $\beta$-haloamines by Gouverneur et al.

high yields up to $98 \%$ and enantioselectivities up to $94 \%$ ee. The key step in this transformation is the formation of the noncovalent catalyst-fluoride complex III during the phasetransfer step. This provides low amounts of reactive, nucleophilic fluoride in the nonpolar solution, circumventing thereby selectivity and reactivity issues owing to the high basicity of alkali metal fluorides [58-62]. By modifying the reaction conditions, the same group was also able to substitute CsF with KF, making their protocol more cost-effective and widening the scope of the reaction to include $\beta$-chloroamines and $\beta$-bromoamines as aziridinium precursors 38 (Scheme 9b). In this way, medicinal interesting $\beta$-fluoroamines $\mathbf{4 0}$ were obtained in good yields and high enantioselectivity up to $95 \%$ ee [63].

\section{Evolution of catalyst designs: from bidentate to supramolecular multidentate anion-binding catalysts}

Despite the evident potential that anion-binding catalysis showed in the pioneering publications - especially in regard to exerting high stereocontrol -, the strategy was still faced with typical limiting factors of hydrogen bond donor catalysis, ranging from high catalyst loadings to high dilution, long reaction times and, in some cases, insufficient chirality transfer into the products. As a consequence, many efforts have been spent to overcome those limitations. Some of them rely on the design of more efficient H-donor catalyst structures, offering additional noncovalent interactions in order to provide extra coordination points with the anion, substrate and/or reagent. The most important approaches in this direction used to date are presented in the following.

\section{(Thio)urea and squaramide catalysts' designs}

Basic/nucleophilic - H-donor bifunctional catalysts: Over the past decades, chiral bifunctional catalysts bearing a thiourea as HB-donor and a basic or nucleophilic group such as an amine have emerged as a powerful tool in organocatalysis by assisting to enhance the catalyst performance and fixation of both reaction partners [64-66]. This strategy has also been used in the field of anion-binding catalysis, by designing hydrogen bond donor catalysts with the appropriate additional functionalities in their chiral backbone (Scheme 10a). Some examples have been already presented in the previous sections. For example, catalyst $\mathbf{2 5}$ bearing a nucleophilic aminoalcohol functionality interacts with the boronic acid reagent in the Reissert-type reaction with acylated quinolines (Scheme 5b) [36], while the phosphine moiety in the bifunctional phosphinothiourea catalyst $\mathbf{3 1}$ allows for heterolytic cleavage of $\mathrm{HCl}$ as displayed in Scheme 7 [55].

Moreover, other catalysts with amine functional groups were found more efficient in the enantioselective $\alpha$-alkylation of aldehydes (Scheme 10b) [48] or in the asymmetric Mannich synthesis of $\alpha$-amino esters using Takemoto's bifunctional catalyst 44 [67] (Scheme 10c) described by Jacobsen and co-workers in 2010 and 2014, respectively [50]. In the one hand, while the thiourea unit in catalyst $\mathbf{4 3}$ abstracts the bromide in $\mathbf{4 5}$ and forms an electrophilic benzhydryl cation, the 
<smiles>CCN(C)C1CCCCC1NC(=S)Nc1cc(C(F)(F)F)cc(C(F)(F)F)c1</smiles>

25

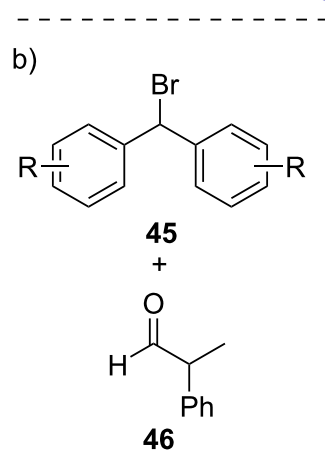<smiles>CC(C)CNC(=O)[C@H](NC(=S)N[C@H]1CCCC[C@@H]1Pc1ccccc1)C1(C)CCCCC1</smiles>

31<smiles>N[C@@H]1CCCC[C@H]1NC(=S)Nc1cc(C(F)(F)F)cc(C(F)(F)F)c1</smiles>

43<smiles>CN(C)[C@H]1CCCC[C@H]1NC(=S)Nc1cc(C(F)(F)F)cc(C(F)(F)F)c1</smiles>

44
$\mathrm{H}_{2} \mathrm{O}, \mathrm{NEt}_{3}, \mathrm{AcOH}$ catalyst 46

toluene, $\mathrm{rt}$<smiles>[R][R]1ccccc1C(c1ccccc1)C([Z7])([R])C(C)(C)C(=O)O</smiles><smiles>[R][R]1ccc(C(=CC=C)c2ccccc2)cc1</smiles>

c)<smiles>CCOC(=O)[C@H](Cl)NC(=O)OCc1ccccc1</smiles>

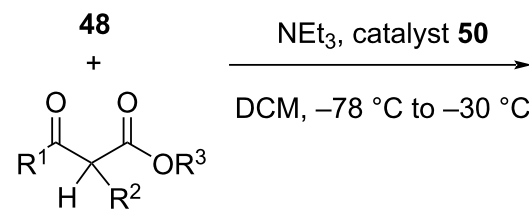<smiles>[R1]OC(=O)C([R])(C([R])=O)C(NC(=O)OCc1ccccc1)C(=O)OCC</smiles>

50

18 examples up to $95 \%$ yield up to $98 \%$ ee

Scheme 10: a) Bifunctional thiourea anion-binding - basic/nucleophilic catalysts. Selected applications in b) enantioselective $\alpha$-alkylation of aldehydes, and c) asymmetric Mannich synthesis of $\alpha$-amino esters.

free amine group activates the aldehyde substrate $\mathbf{4 6}$. The resulting enamine can then serve as the nucleophile as displayed in the key intermediate shown in Scheme 10b. As a result, yields up to $70 \%$ and excellent enantioselectivities up to $94 \%$ ee could be achieved at room temperature. On the other hand, the secondary amine group in Takemoto's catalyst $\mathbf{4 4}$ acts as a base, abstracting the proton of the enolizable $\beta$-ketoester 49 and thus activating the nucleophilic species. This enolate then adds to the cationic substrate from in situ upon halide abstraction of $\alpha$-chloro amino acid derivatives $\mathbf{4 8}$ by the thiourea moiety of the bifunctional catalyst (Scheme 10c, key intermediate), leading to excellent yields and enantioselectivities up to $95 \%$ and $98 \%$ ee, respectively.

Cation- $\pi$ interaction: expanding the functionality of hydrogen bond donor catalysts: The development of hydrogen bond donor anion-binding catalysts mainly focuses on the interaction and binding properties towards the anionic species. However, the cationic counterpart can have important effects on the kinetics of the systems. This hypothesis has evidently been identified in enzymatic reactions [68]. Mechanistic studies have shown that in such processes, cationic species are stabilized through various attractive interactions with aromatic residues of the enzymes. In fact, these additional stabilizing effects can be exploited in the design of more effective noncovalent catalytic structures for anion-binding catalysis. In this regard, cation $-\pi$ interactions have been used to develop several types of anion binding-catalyzed transformations such as cyclizations or nucleophilic additions.

Inspired by cationic terpene-type cyclization cascades, Jacobsen's group turned their attention to the structure and properties of the chiral part of thiourea catalysts by introducing extended $\pi$-groups. A series of thiourea catalysts 53-55 with varying aromatic residues were synthesized to elucidate if interactions with the anionic and cationic species could simultaneously be achieved. Hence, in 2010, they successfully showed that such rather small catalysts can mimic nature's principle of 
cation $-\pi$ interactions, allowing for a highly enantioselective polycylization reaction of $\mathbf{5 1}$ (Scheme 11) [69]. Modification of the aromatic ring system on the chiral side of the thiourea catalyst proved to be crucial, as both the reactivity and the enantioselectivity were significantly influenced by the stabilization of the cationic substrate and not by interactions with the anion. Specifically, extension of the aromatic system from the simple phenyl (53) over the 1-naphthyl (54) to the 4-pyrenyl (55) substituent led to improved yields from $12 \%$ to $72 \%$ and enantioselectivities from $25 \%$ to $94 \%$ ee.

In 2016 , this cation- $\pi$ strategy was further employed for the development of an enantioselective aza-Sakurai cyclization (Scheme 12) [70]. In this transformation, a chiral thiourea catalyst $\mathbf{5 8}$ with a dibenzothiophene functionality serves as a dual $\mathrm{H}$-bond donor and Lewis base to facilitate the cyclization of hydroxylactams 56. Thus, indolizine and quinolidizine frameworks $\mathbf{5 7}$ were accessed in excellent yields up to $93 \%$ and enantioselectivities up to $94 \%$ ee. Increased aromaticity proved again to be essential for achieving high enantioselectivities. Additionally, Lewis base activation of the allylsilane substrates through the thiourea sulfur atom is proposed to be crucial, while the urea analog of the catalysts proved less efficient and led to diminished reactivity and stereoselectivity. Further mechanistic studies corroborated this hypothesis as more electron-rich allylsilane derivatives were consumed slower despite being inherently more nucleophilic.

Another example highlighting the importance of sidechain catalyst design was given by Jacobsen et al. in the tail-to-head cycli-

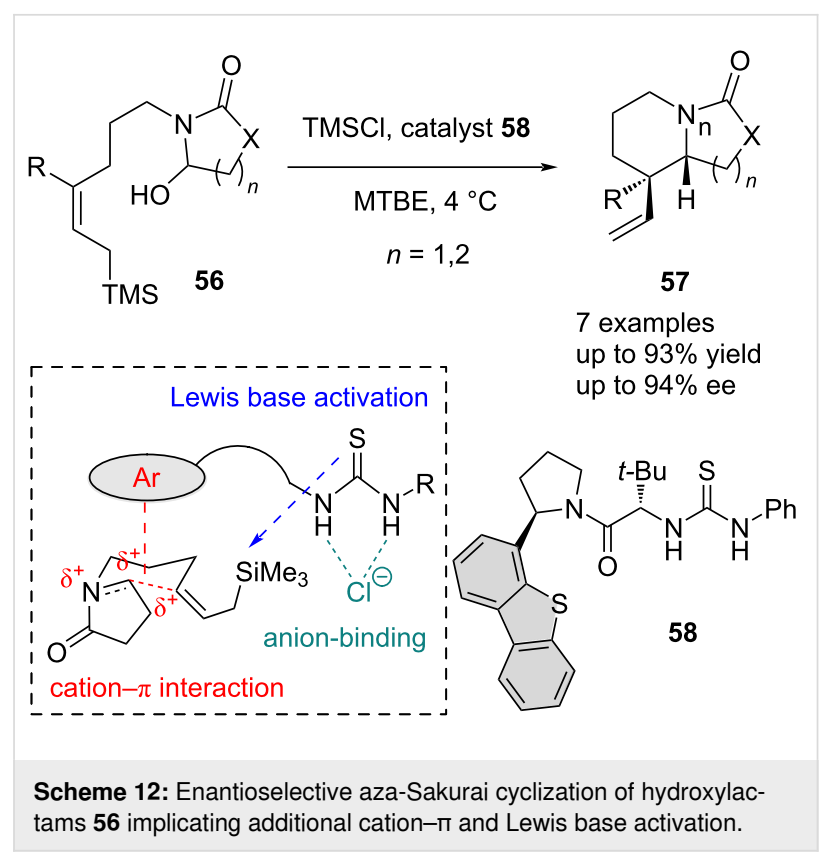

zation of neryl chloride and derivatives $\mathbf{5 9}$ (Scheme 13) [17]. Mechanistic studies and DFT calculations revealed that an extended $\pi$-system in the sidechain of the bidentate urea catalyst 61 was required to form the key aggregate involving two catalyst molecules and the substrate. This complex is the one involved in the rate and enantio-determining ionization step, allowing to furnish the desired products $\mathbf{6 0}$ in up to $93 \%$ ee.

Finally, similar examples utilizing cation $-\pi$ interactions have been provided by the group of Jacobsen in the nucleophilic ad-

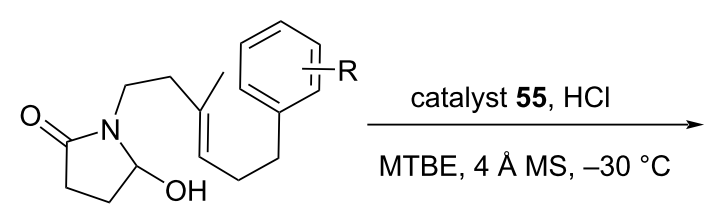

51<smiles>[R]c1cccc2c1CC[C@@H]1[C@@H]2CC[C@]12CCN1C(=O)CC[C@@H]12</smiles>

52

7 examples up to $77 \%$ yield up to $94 \%$ ee

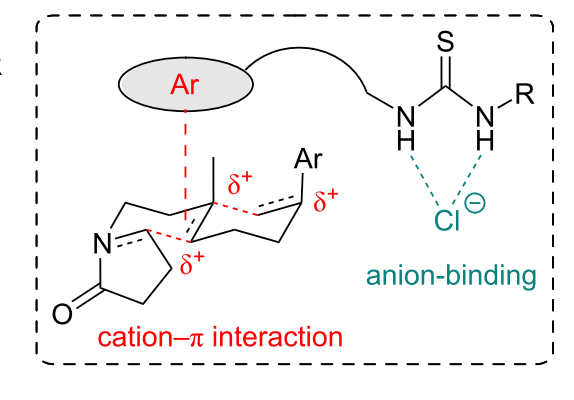<smiles>CC(C)(C)C(NC(=S)Nc1cc(C(F)(F)F)cc(C(F)(F)F)c1)C(=O)N1CCC[C@H]1c1ccccc1</smiles>

53

$12 \%$ yield

$25 \%$ ee<smiles>CC(C)(C)C(NC(=S)Nc1cc(C(F)(F)F)cc(C(F)(F)F)c1)C(=O)N1CCCC1c1cccc2ccccc12</smiles>

$46 \%$ yield

$60 \%$ ee<smiles>Cc1cc(C)c2c(C)cccc2c1C1CCCN1C(=O)C(NC(=S)Nc1cc(C(F)(F)F)cc(C(F)(F)F)c1)C(C)(C)C</smiles>

$72 \%$ yield $94 \%$ ee 


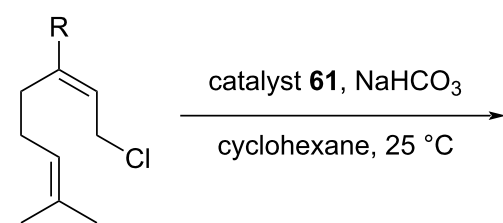

59

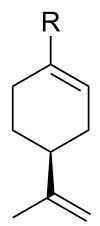

60

9 examples up to $72 \%$ yield up to $93 \%$ ee

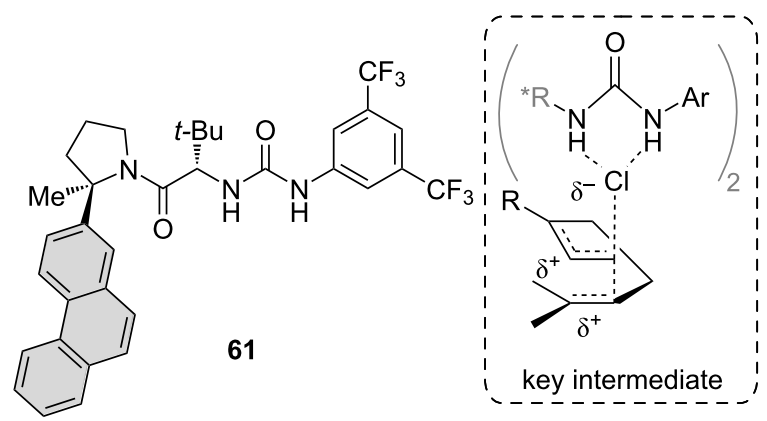

Scheme 13: Enantioselective tail-to-head cyclization of neryl chloride derivatives. dition of indoles 17 to pyranones 62 (Scheme 14a) [71], as well as in the enantioselective synthesis of $\alpha$-allyl amino esters 67 by the reaction of $\alpha$-chloro amino acid derivatives $\mathbf{6 5}$ with allyltin and allylsilane $\mathbf{6 6}$ nucleophiles [72] (Scheme 14b). In both cases, an extended $\pi$-system on the side chain of the chiral thio- urea catalysts is able to interact with the reactant and was required to achieve high enantioinductions, providing the corresponding products in excellent yields up to $95 \%$ and enantioselectivities up to $96 \%$ and $97 \%$ ee, respectively.

\section{Bis- and macrocyclic thiourea catalysts}

Besides the introduction of cation $-\pi$ interactions in anionbinding catalyst design, bisthiourea catalysts have been applied with the aim of accelerating certain catalytic reactions. In this regard, the group of Seidel reported in 2016 an enantioselective $\mathrm{HCl}$ co-catalyzed oxa-Pictet-Spengler reaction employing bisthiourea catalyst $\mathbf{7 2}$ bearing two aliphatic groups at one of the nitrogen atoms of one thiourea (Scheme 15) [51]. The key intermediate in this reaction system is the contact ion pair of the thiourea catalyst with the in situ-generated oxycarbenium ion, which enables high enantioselectivities up to $95 \%$ ee and yields up to $91 \%$. Furthermore, an investigation of the involved halide counter-anion revealed that chloride was the most potent one in regards of both yield and enantioinduction. Bromine and iodine on the other hand, afforded the final product $\mathbf{7 1}$ in lower yields ( $71 \%$ and $90 \%$ ) and also a detriment in enantioinduction was observed with $76 \%$ and $46 \%$ ee, respectively.

Alternatively, Jacobsen's group carried out a series of studies to elucidate whether the targeted design of a catalyst can increase its efficiency for a given reaction [73-76]. For this purpose, based on their initial findings in 2008 [38], the enantioselective addition of silyl ketene acetals to racemic 1-chloroisochromane

a)<smiles>[R]c1[nH]c2c(c1[R])=C[R]C=CC=2</smiles>

17

62<smiles>O=c1ccoc(CBr)c1[O+]S(=O)(=O)c1ccccc1</smiles>
catalyst $64, \mathrm{BzOH}$

TBME, $30^{\circ} \mathrm{C}$<smiles>[R]C1=Nc2ccccc2C1([R])Cc1occc(=O)c1O</smiles>

63

14 examples up to $95 \%$ yield up to $96 \%$ ee<smiles>C=CC=CC(=C)c1cc(-c2ccc3ccccc3c2)cc([C@@H]2CCCN2C(=O)[C@H](NC(=S)Nc2cc(C(F)(F)F)cc(C(F)(F)F)c2)C(C)(C)C)c1</smiles>

64

b)

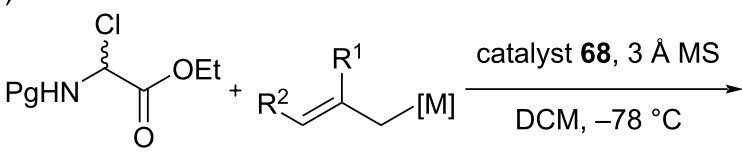

65

66

[M] $=\mathrm{SnR}_{4}, \mathrm{SiR}_{3}$<smiles>[R]C(=C)C([R])[C@H](N[PbH])C(=O)OCC</smiles>

67

15 examples up to $95 \%$ yield up to $97 \%$ ee<smiles>CC(C)(C)C(Nc1c(Nc2cc(C#N)cc(C#N)c2)c(=O)c1=O)C(=O)N1CCC[C@]1(C)c1ccc2c(ccc3ccccc32)c1</smiles> 
<smiles>OCCc1c[nH]c2cc[R]cc12</smiles>

69<smiles>O=Cc1cc[R]cc1</smiles>

70

(S)-methyl indoline-2carboxylate $\cdot \mathrm{HCl}$ catalyst 72

toluene, $4 \AA \mathrm{MS},-30^{\circ} \mathrm{C}$<smiles></smiles>

71

16 examples up to $91 \%$ yield up to $95 \%$ ee

Scheme 15: Bisthiourea catalyzed oxa-Pictet-Spengler reaction of indole-based alcohols and aromatic aldehydes under weakly acidic conditions.

(73) was more closely examined (Scheme 16) [73-76]. In this type of reaction, thiourea catalyst $\mathbf{7 6}$ actively engages in the ionization step by chloride abstraction that leads to the formation of an oxocarbenium intermediate, which then undergoes the stereoselective addition of the nucleophile. Mechanistic insights revealed that two thiourea molecules are, in fact, needed and cooperatively participate in the activation of $\mathbf{7 3}$. However, nonproductive dimeric aggregates form under standard reaction conditions. These dimers exist in different combi- nations of the thiourea rotamers and lead to competing catalytic pathways (Scheme 16a). Moreover, anion abstraction was calculated to proceed either through a $4 H$ abstraction mechanism of two thioureas binding simultaneously to the chloride or through a cooperative $2 \mathrm{H}$ abstraction mechanism. These findings proved to be decisive in the development of new and more efficient anion-binding catalysts. By introducing a methyl group $(\mathrm{R}=\mathrm{Me})$ into the pyrrolidine moiety of the initial catalyst design, the amide is conformationally constricted to the $(Z)$ -<smiles>ClC1OCCc2ccccc21</smiles>

73<smiles>COc1ccc(OC)c(OC)c1</smiles>

74 a)<smiles>[R][C@]1(c2ccc(F)cc2)CCCN1C(=O)[C@@H](NC(=S)Nc1cc(C(F)(F)F)cc(C(F)(F)F)c1)C(C)(C)C</smiles>
catalytic active monomers

(if $\mathrm{R}=\mathrm{H}$ : formation of rotamers with competing catalytic activity)

$\mathrm{R}=\mathrm{H}, 66 \%$ conv., $92 \%$ ee

$\mathrm{R}=\mathrm{Me},>95 \%$ conv., $97 \%$ ee

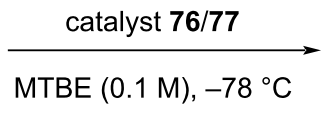

b)<smiles>CC(C)(C)CCOC(=O)c1cc(C(=O)N2CCC[C@]2(C)c2ccc(F)cc2)cc(N(NC(=S)Nc2cc(C(F)(F)F)cc(C(F)(F)F)c2)C(=S)N[C@H](C(=O)N2CCC[C@]2(C)c2ccc(F)cc2)C(C)(C)C)c1</smiles><smiles>COC(=O)C(C)(C)[C@H]1OCCc2ccccc21</smiles>

75

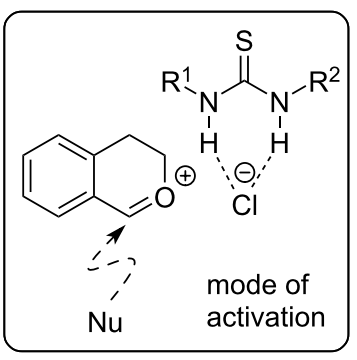

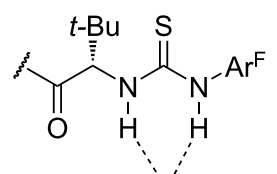

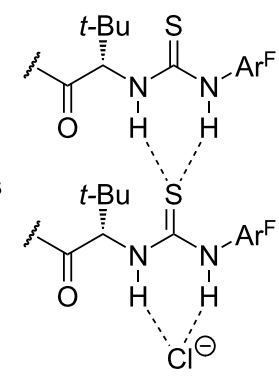

$4 \mathrm{H}$ anion abstraction (Z)-rotamer only

$2 H$ anion abstraction 
rotamer [75]. Consequently, improved enantioselectivity and catalytic efficiency could be observed ( $>95 \%$ conv., 97\% ee) This design was then further refined by covalently linking two thiourea molecules together to give bis-thiourea catalyst $\mathbf{7 7}$ (Scheme 16b) [76]. Due to the linkage of the two molecules, the participating hydrogen bonds are aligned such that a $4 H$-abstraction mode is achieved, which is more likely to ensure higher catalyst activity in the activation step than the competing $2 \mathrm{H}$-abstraction pathway. Indeed, with multidentate bis-thiourea catalyst 77, the catalyst loading could be decreased from 10 to only $0.1 \mathrm{~mol} \%$ without significant loss of enantioselectivity (96\% yield, 92\% ee). Ultimately, this work gave a tremendous insight and a myriad of applications of such bis-thiourea catalysts with halogen counter-anions and phosphates [73-78].

Nevertheless, the activation of $\alpha$-chloro ethers via anion abstraction continued to be a foundation for anion-binding catalyst evolution. In fact, Jacobsen's group further refined the design of their tetradentate $\mathrm{N}-\mathrm{H}$-bond donor catalyst $\mathbf{8 0}$ by covalently linking it into the more rigid macrocycle $\mathbf{8 1}$ (Scheme 17a) [78]. Compared to bis-thiourea 80, the higher rigidity in the macrocycle $\mathbf{8 1}$ not only enforces halide abstraction significantly, but also allowed for a better control of the stereoselectivity in the glycosylation of glycosyl halides $\mathbf{7 8}$ with a variety of coupling partners. In this way, the corresponding $\beta$-glycosides 79 were almost exclusively obtained (up to $88 \%$ yield, up to $98 \%$ ee). The reaction was found to proceed stereospecifically with inversion of the anomeric configuration and, therefore, being dependent on the configuration of the electrophilic partner 78. With this observation, the reaction was concluded to proceed via a $S_{N} 2$ mechanism. However, mechanistic investigations revealed the existence of a competing $\mathrm{S}_{\mathrm{N}} 1$ pathway featuring an oxocarbenium cation, which explains the formation of the minor diastereoisomer (Scheme 17b).

\section{Non-thiourea-based supramolecular catalysts}

The combination of anion-binding catalysis and supramolecular chemistry is a fairly new arisen field, with a set number of notable examples [79-83]. Next to thioureas, investigations in this area of anion binding were also conducted for other catalytic systems. In 2014, the García group reported a family of chiral helical tetratriazoles 82 as a new class of anion-binding catalysts, which can be considered as supramolecular anion-binding catalysts (Scheme 18) [22]. Not only is the increased H-bonding network in multidentate $\mathbf{8 2}$ beneficial for giving a firm control over both regio- and enantioselectivity, but the catalyst itself accommodates the anion by adopting a helical conformation upon complexation (Scheme 18a) [84-86]. Initial studies proved these systems highly effective for the enantioselective Reissert reaction of quinolines with silyl ketene acetals [22], which could be later extended to other $N$ - and $O$-heteroarenes and various nucleophiles (Scheme 18b) [87-91].

Computational studies on the helical tetrakistriazole catalyst were additionally carried out, aiming at gaining insight into its interactions with the anion and cationic counterpart of the ionic a)

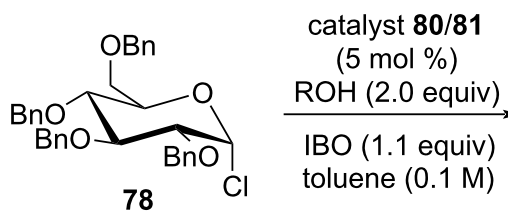

$\mathrm{ROH}=\mathrm{BnOH}, \mathrm{MeOH}$, menthol, glycosyl nucleophiles

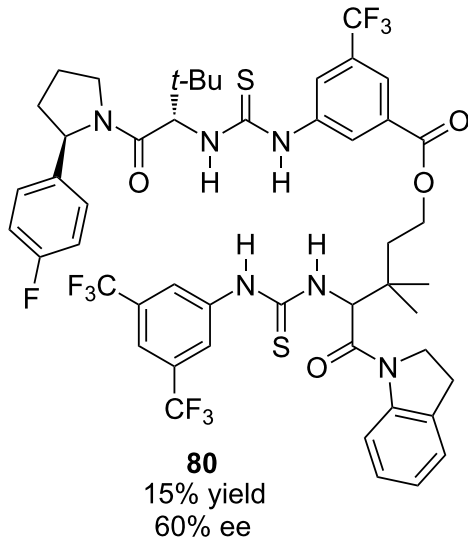

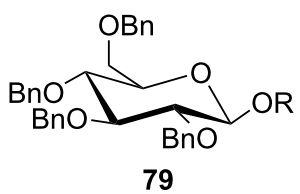

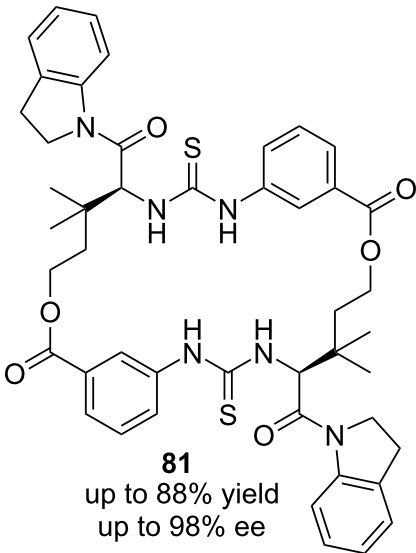

b)

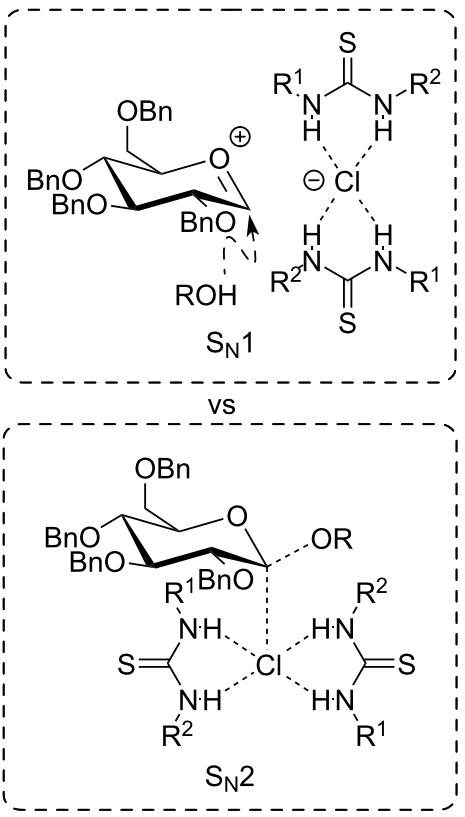




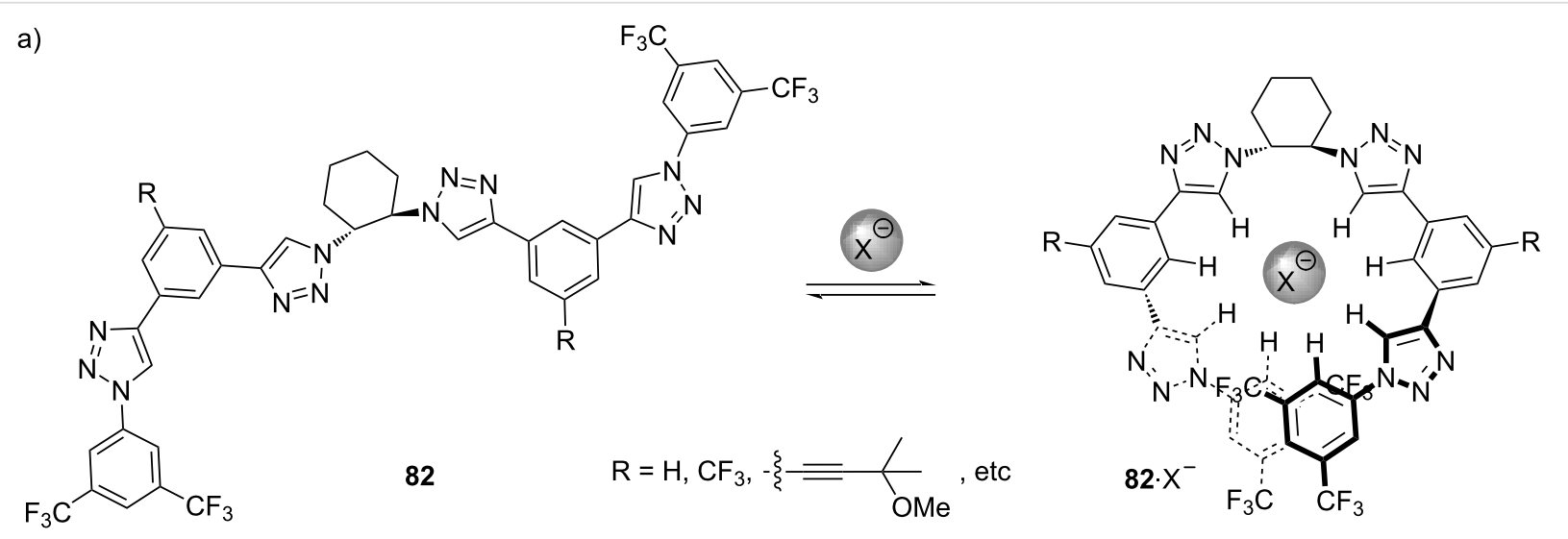

b)<smiles></smiles>

83

\section{1) $\operatorname{TrocCl}, 0^{\circ} \mathrm{C}, \mathrm{MTBE}$}

2) catalyst $70(0.05-10 \mathrm{~mol} \%)$ nucleophile, $-78{ }^{\circ} \mathrm{C}$

$\begin{array}{|ll|}\text { e.g. OTBS } & \begin{array}{l}17 \text { examples } \\ \text { OiPr to } 96 \% \text { yield } \\ \text { up to } 96 \% \text { ee }\end{array} \\ & \text { Oipr }\end{array}$

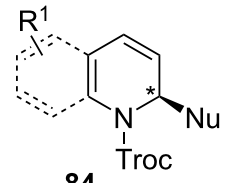

84

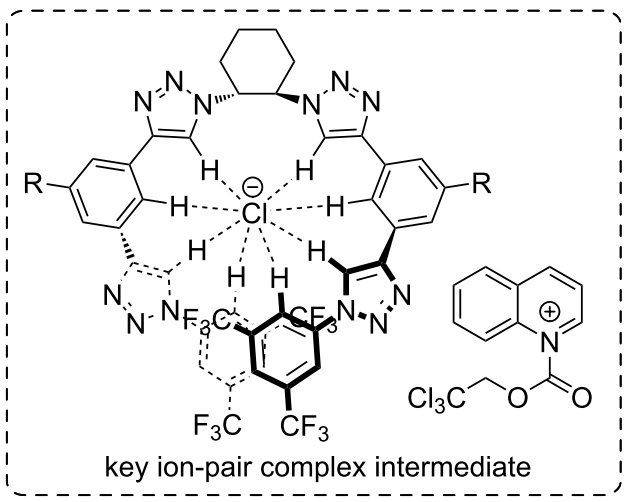

Scheme 18: a) Folding mechanism of oligotriazoles upon anion recognition. b) Representative tetratriazole 82 catalyzed enantioselective Reisserttype reaction of quinolines and pyridines with various nucleophiles.

substrate [86]. Besides the contact to the chloride anion, investigations with tetrabutylammonium chloride $(\mathrm{TBACl})$ and pyridinium chloride salt as model compounds found evidence for productive interactions between the catalyst and the cations. However, these interactions may not solely be attributed to cation $-\pi$, but also to cation- $\mathrm{H}$ or $\pi-\pi$ interactions.

Some of the advantages of multidentate, supramolecular anionbinding catalysis were recently exploited by the Feringa group, who designed an anion-binding catalyst 86 that fuses the known triazole binding properties with a light-switchable molecular motor. In this way, they were not only able to control the folding of the triazole units through successive irradiation and thermal excitation, but they could also selectively control the stereochemical outcome of the benchmark reaction of 1-chloroisochromane (73) with silylketene acetals (Scheme 19) [92].

Such examples, and the advance of anion-binding-catalyzed strategies involving more complex H-bonding networks clearly highlight that it is indeed possible to mimic enzyme-like structures with small-molecule catalysts for asymmetric synthesis.

\section{Conclusion}

In the past two decades, tremendous advances in the field of anion-binding catalysis have been made, evolving as a valuable addition to the synthetic toolbox.

In this review, we have presented the essential role that halide anions, especially chloride, have played in the development of this area of research in the past decades. From the initial endeavors, in which differentiation between classical H-bonding to neutral substrates and the binding to anionic species was delineated, anion-binding interactions became more prominent and started being considered in the design of new syntheses and catalytic approaches. In this context, the emphasis was to display the role of the halide anions and how the predictability of binding properties towards these anions led to the development of a multitude of catalytic concepts and (supramolecular) catalyst systems. Hence, the possibility of employing the catalyst-bound halide anions in the key ion pair complexes as active nucleophiles were also featured. Though less explored so far than their use as simple, inert counter-anions to build the ion pair, this approach provides new possibilities and substantially broadens the synthetic applicability of anion-binding catalysis. Finally, the evolution from simple H-bonding to complex halide 


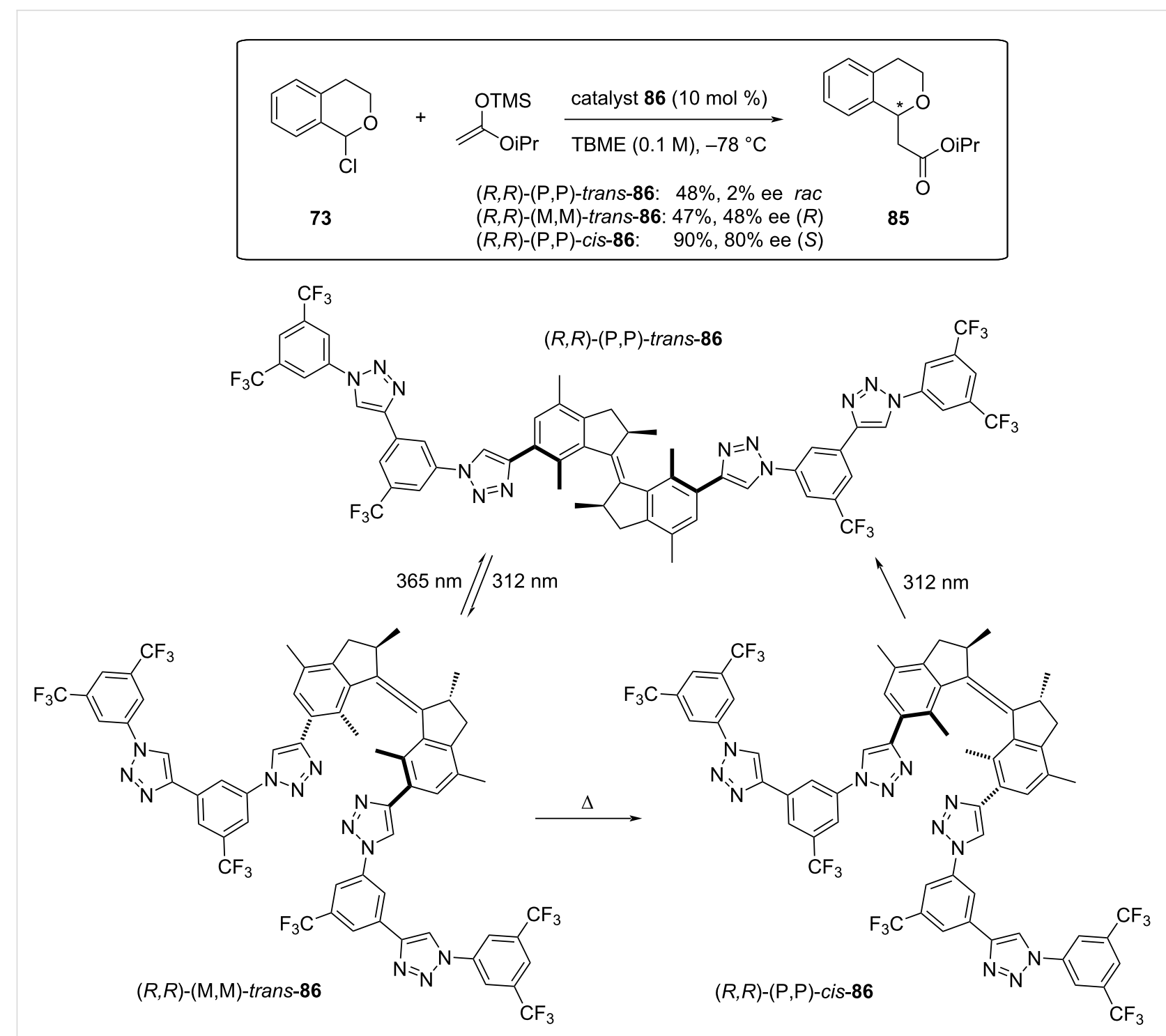

Scheme 19: Switchable chiral tetratriazole catalyst 86 in the enantioselective addition of silyl ketene acetals to 1-chloroisochromane.

anion-binding catalyst designs has been outlined. Recent reports show that synthetic and computational research become more intertwined, and a trend towards multiple noncovalent interactions, as well as supramolecular chemistry, might be in-bound soon.

Based on the tremendous developments in this field thus far, important advances in the understanding of complex anionbinding processes, the design of more potent, efficient catalysts, and the development of innovative activations and reactions can be certainly envisioned to be further evolved in the near future.

\section{Funding}

The European Research Council (ERC-CG 724695) and the Deutsche Forschungsgemeinschaft (DFG) within the SFB858 are gratefully acknowledged for their generous support. L.S. also thanks the DFG, as well as K.K. and M.S. the EU-council for their doctoral contracts.

\section{ORCID ${ }^{\circledR}$ iDs}

Lukas Schifferer - https://orcid.org/0000-0001-6183-8948

Olga García Macheño - https://orcid.org/0000-0002-7578-5418

\section{References}

1. Gribble, G. W. J. Chem. Educ. 2004, 81, 1441-1449. doi:10.1021/ed081p1441

2. Neumann, C. S.; Galonić Fujimori, D.; Walsh, C. T. Chem. Biol. 2008, 15, 99-109. doi:10.1016/j.chembiol.2008.01.006

3. Davis, A. P.; Sheppard, D. N.; Smith, B. D. Chem. Soc. Rev. 2007, 36, 348-357. doi:10.1039/b512651g 
4. Evano, G. Synthesis from Organic Halides. In Compounds with Four and Three Carbon Heteroatom Bonds; Panek, J. S., Ed.; Science of Synthesis; Thieme Verlag: Stuttgart, Germany, 2006. doi:10.1055/sos-sd-020-00102

5. Busschaert, N.; Caltagirone, C.; Van Rossom, W.; Gale, P. A. Chem. Rev. 2015, 115, 8038-8155. doi:10.1021/acs.chemrev.5b00099

6. Dutzler, R.; Campbell, E. B.; Cadene, M.; Chait, B. T.; MacKinnon, R. Nature 2002, 415, 287-294. doi:10.1038/415287a

7. Bianchi, A.; Bowman-James, K.; García-España, E., Eds. Supramolecular Chemistry of Anions; Wiley-VCH: Weinheim, Germany, 1997.

8. Park, C. H.; Simmons, H. E. J. Am. Chem. Soc. 1968, 90, 2431-2432. doi:10.1021/ja01011a047

9. Beer, P. D.; Gale, P. A. Angew. Chem., Int. Ed. 2001, 40, 486-516. doi:10.1002/1521-3773(20010202)40:3<486::aid-anie486>3.0.co;2-p

10. Zhang, Z.; Schreiner, P. R. Chem. Soc. Rev. 2009, 38, 1187-1198. doi:10.1039/b801793j

11. Schmidtchen, F. P.; Berger, M. Chem. Rev. 1997, 97, 1609-1646. doi:10.1021/cr9603845

12. Gale, P. A.; Sessler, J. L.; Král, V. Chem. Commun. 1998, 1-8. doi:10.1039/a706280j

13. Fan, E.; Van Arman, S. A.; Kincaid, S.; Hamilton, A. D. J. Am. Chem. Soc. 1993, 115, 369-370. doi:10.1021/ja00054a066

14. Smith, P. J.; Reddington, M. V.; Wilcox, C. S. Tetrahedron Lett. 1992, 33, 6085-6088. doi:10.1016/s0040-4039(00)60012-6

15. Brak, K.; Jacobsen, E. N. Angew. Chem., Int. Ed. 2013, 52, 534-561. doi:10.1002/anie.201205449

16. Zhang, H.; Lin, S.; Jacobsen, E. N. J. Am. Chem. Soc. 2014, 136, 16485-16488. doi:10.1021/ja510113s

17. Kutateladze, D. A.; Strassfeld, D. A.; Jacobsen, E. N. J. Am. Chem. Soc. 2020, 142, 6951-6956. doi:10.1021/jacs.0c02665

18. Pupo, G.; Ibba, F.; Ascough, D. M. H.; Vicini, A. C.; Ricci, P.; Christensen, K. E.; Pfeifer, L.; Morphy, J. R.; Brown, J. M.; Paton, R. S.; Gouverneur, V. Science 2018, 360, 638-642. doi:10.1126/science.aar7941

19. Schafer, A. G.; Wieting, J. M.; Fisher, T. J.; Mattson, A. E. Angew. Chem., Int. Ed. 2013, 52, 11321-11324. doi:10.1002/anie.201305496

20. Attard, J. W.; Osawa, K.; Guan, Y.; Hatt, J.; Kondo, S.-i.; Mattson, A. Synthesis 2019, 51, 2107-2115. doi:10.1055/s-0037-1612217

21. Ohmatsu, K.; Hamajima, Y.; Ooi, T. J. Am. Chem. Soc. 2012, 134, 8794-8797. doi:10.1021/ja3028668

22. Zurro, M.; Asmus, S.; Beckendorf, S.; Mück-Lichtenfeld, C.; García Mancheño, O. J. Am. Chem. Soc. 2014, 136, 13999-14002. doi:10.1021/ja507940k

23. Beckendorf, S.; Asmus, S.; García Mancheño, O. ChemCatChem 2012, 4, 926-936. doi:10.1002/cctc.201200134

24. Phipps, R. J.; Hamilton, G. L.; Toste, F. D. Nat. Chem. 2012, 4, 603-614. doi:10.1038/nchem.1405

25. Mahlau, M.; List, B. Angew. Chem., Int. Ed. 2013, 52, 518-533. doi:10.1002/anie.201205343

26. Evans, N. H.; Beer, P. D. Angew. Chem., Int. Ed. 2014, 53 , 11716-11754. doi:10.1002/anie.201309937

27. Seidel, D. Synlett 2014, 25, 783-794. doi:10.1055/s-0033-1340618

28. Visco, M. D.; Attard, J.; Guan, Y.; Mattson, A. E. Tetrahedron Lett. 2017, 58, 2623-2628. doi:10.1016/j.tetlet.2017.05.045

29. García Mancheño, O., Ed. Anion-Binding Catalysis; Wiley-VCH: Weinheim, Germany, 2021.

30. Kotke, M.; Schreiner, P. R. Tetrahedron 2006, 62, 434-439. doi:10.1016/j.tet.2005.09.079
31. Kotke, M.; Schreiner, P. R. Synthesis 2007, 779-790. doi:10.1055/s-2007-965917

32. Taylor, M. S.; Jacobsen, E. N. J. Am. Chem. Soc. 2004, 126, 10558-10559. doi:10.1021/ja046259p

33. Raheem, I. T.; Thiara, P. S.; Peterson, E. A.; Jacobsen, E. N. J. Am. Chem. Soc. 2007, 129, 13404-13405. doi:10.1021/ja076179w

34. Raheem, I. T.; Thiara, P. S.; Jacobsen, E. N. Org. Lett. 2008, 10, 1577-1580. doi:10.1021/ol800256j

35. Peterson, E. A.; Jacobsen, E. N. Angew. Chem., Int. Ed. 2009, 48, 6328-6331. doi:10.1002/anie.200902420

36. Taylor, M. S.; Tokunaga, N.; Jacobsen, E. N. Angew. Chem., Int. Ed. 2005, 44, 6700-6704. doi:10.1002/anie.200502277

37. Yamaoka, Y.; Miyabe, H.; Takemoto, Y. J. Am. Chem. Soc. 2007, 129, 6686-6687. doi:10.1021/ja071470x

38. Reisman, S. E.; Doyle, A. G.; Jacobsen, E. N. J. Am. Chem. Soc. 2008, 130, 7198-7199. doi:10.1021/ja801514m

39. Choudhury, A. R.; Mukherjee, S. Chem. Sci. 2016, 7, 6940-6945. doi:10.1039/c6sc02466a

40. Matador, E.; Iglesias-Sigüenza, J.; Monge, D.; Merino, P.; Fernández, R.; Lassaletta, J. M. Angew. Chem., Int. Ed. 2021, 60, 5096-5101. doi:10.1002/anie.202012861

41. Borovika, A.; Tang, P.-I.; Klapman, S.; Nagorny, P. Angew. Chem., Int. Ed. 2013, 52, 13424-13428. doi:10.1002/anie.201307133

42. Nakamura, T.; Okuno, K.; Nishiyori, R.; Shirakawa, S. Chem. - Asian J. 2020, 15, 463-472. doi:10.1002/asia.201901652

43. Berkessel, A.; Das, S.; Pekel, D.; Neudörfl, J.-M. Angew. Chem., Int. Ed. 2014, 53, 11660-11664. doi:10.1002/anie.201403778

44. Walter, S. M.; Kniep, F.; Herdtweck, E.; Huber, S. M. Angew. Chem., Int. Ed. 2011, 50, 7187-7191. doi:10.1002/anie.201101672

45. Kniep, F.; Jungbauer, S. H.; Zhang, Q.; Walter, S. M.; Schindler, S.; Schnapperelle, I.; Herdtweck, E.; Huber, S. M. Angew. Chem., Int. Ed. 2013, 52, 7028-7032. doi:10.1002/anie.201301351

46. Sutar, R. L.; Engelage, E.; Stoll, R.; Huber, S. M. Angew. Chem., Int. Ed. 2020, 59, 6806-6810. doi:10.1002/anie.201915931

47. Ostler, F.; Piekarski, D. G.; Danelzik, T.; Taylor, M. S.; García Mancheño, O. Chem. - Eur. J. 2021, 27, 2315-2320. doi:10.1002/chem.202005016

48. Brown, A. R.; Kuo, W.-H.; Jacobsen, E. N. J. Am. Chem. Soc. 2010, 132, 9286-9288. doi:10.1021/ja103618r

49. Birrell, J. A.; Desrosiers, J.-N.; Jacobsen, E. N. J. Am. Chem. Soc. 2011, 133, 13872-13875. doi:10.1021/ja205602j

50. Wasa, M.; Liu, R. Y.; Roche, S. P.; Jacobsen, E. N. J. Am. Chem. Soc. 2014, 136, 12872-12875. doi:10.1021/ja5075163

51. Zhao, C.; Chen, S. B.; Seidel, D. J. Am. Chem. Soc. 2016, 138, 9053-9056. doi:10.1021/jacs.6b05225

52. Denmark, S. E.; Kalyani, D.; Collins, W. R. J. Am. Chem. Soc. 2010, 132, 15752-15765. doi:10.1021/ja106837b

53. Denmark, S. E.; Collins, W. R.; Cullen, M. D. J. Am. Chem. Soc. 2009, 131, 3490-3492. doi:10.1021/ja900187y

54. Denmark, S. E.; Edwards, M. G. J. Org. Chem. 2006, 71, 7293-7306. doi:10.1021/j00610457

55. Mita, T.; Jacobsen, E. N. Synlett 2009, 1680-1684. doi:10.1055/s-0029-1217344

56. Strassfeld, D. A.; Wickens, Z. K.; Picazo, E.; Jacobsen, E. N. J. Am. Chem. Soc. 2020, 142, 9175-9180. doi:10.1021/jacs.0c03991 
57. Strassfeld, D. A.; Algera, R. F.; Wickens, Z. K.; Jacobsen, E. N. J. Am. Chem. Soc. 2021, 143, 9585-9594. doi:10.1021/jacs.1c03992

58. Kalow, J. A.; Doyle, A. G. J. Am. Chem. Soc. 2010, 132, 3268-3269. doi:10.1021/ja100161d

59. Katcher, M. H.; Doyle, A. G. J. Am. Chem. Soc. 2010, 132, 17402-17404. doi:10.1021/ja109120n

60. Kalow, J. A.; Doyle, A. G. J. Am. Chem. Soc. 2011, 133, 16001-16012. doi:10.1021/ja207256s

61. Katcher, M. H.; Sha, A.; Doyle, A. G. J. Am. Chem. Soc. 2011, 133, 15902-15905. doi:10.1021/ja206960k

62. Suzuki, S.; Kamo, T.; Fukushi, K.; Hiramatsu, T.; Tokunaga, E.; Dohi, T.; Kita, Y.; Shibata, N. Chem. Sci. 2014, 5, 2754-2760. doi:10.1039/c3sc53107d

63. Pupo, G.; Vicini, A. C.; Ascough, D. M. H.; Ibba, F.; Christensen, K. E.; Thompson, A. L.; Brown, J. M.; Paton, R. S.; Gouverneur, V. J. Am. Chem. Soc. 2019, 141, 2878-2883. doi:10.1021/jacs.8b12568

64. Serdyuk, O. V.; Heckel, C. M.; Tsogoeva, S. B. Org. Biomol. Chem. 2013, 11, 7051-7071. doi:10.1039/c3ob41403e

65. Parvin, T.; Yadav, R.; Choudhury, L. H. Org. Biomol. Chem. 2020, 18, 5513-5532. doi:10.1039/d0ob00595a

66. Sun, Y.-L.; Wei, Y.; Shi, M. ChemCatChem 2017, 9, 718-727. doi:10.1002/cctc.201601144

67. Okino, T.; Hoashi, Y.; Takemoto, Y. J. Am. Chem. Soc. 2003, 125, 12672-12673. doi:10.1021/ja036972z

68. Shi, Z.; Buntel, C. J.; Griffin, J. H. Proc. Natl. Acad. Sci. U. S. A. 1994, 91, 7370-7374. doi:10.1073/pnas.91.15.7370

69. Knowles, R. R.; Lin, S.; Jacobsen, E. N. J. Am. Chem. Soc. 2010, 132, 5030-5032. doi:10.1021/ja101256v

70. Park, Y.; Schindler, C. S.; Jacobsen, E. N. J. Am. Chem. Soc. 2016, 138, 14848-14851. doi:10.1021/jacs.6b09736

71. Yeung, C. S.; Ziegler, R. E.; Porco, J. A., Jr.; Jacobsen, E. N. J. Am. Chem. Soc. 2014, 136, 13614-13617. doi:10.1021/ja508523g

72. Bendelsmith, A. J.; Kim, S. C.; Wasa, M.; Roche, S. P.; Jacobsen, E. N. J. Am. Chem. Soc. 2019, 141, 11414-11419. doi:10.1021/jacs.9b05556

73. Ford, D. D.; Lehnherr, D.; Kennedy, C. R.; Jacobsen, E. N. J. Am. Chem. Soc. 2016, 138, 7860-7863. doi:10.1021/jacs.6b04686

74. Ford, D. D.; Lehnherr, D.; Kennedy, C. R.; Jacobsen, E. N. ACS Catal. 2016, 6, 4616-4620. doi:10.1021/acscatal.6b01384

75. Lehnherr, D.; Ford, D. D.; Bendelsmith, A. J.; Kennedy, C. R.; Jacobsen, E. N. Org. Lett. 2016, 18, 3214-3217. doi:10.1021/acs.orglett.6b01435

76. Kennedy, C. R.; Lehnherr, D.; Rajapaksa, N. S.; Ford, D. D.; Park, Y.; Jacobsen, E. N. J. Am. Chem. Soc. 2016, 138, 13525-13528. doi:10.1021/jacs.6b09205

77. Mayfield, A. B.; Metternich, J. B.; Trotta, A. H.; Jacobsen, E. N. J. Am. Chem. Soc. 2020, 142, 4061-4069. doi:10.1021/jacs.0c00335

78. Park, Y.; Harper, K. C.; Kuhl, N.; Kwan, E. E.; Liu, R. Y.; Jacobsen, E. N. Science 2017, 355, 162-166. doi:10.1126/science.aal1875

79. Eichstaedt, K.; Jaramillo-Garcia, J.; Leigh, D. A.; Marcos, V.; Pisano, S.; Singleton, T. A. J. Am. Chem. Soc. 2017, 139, 9376-9381. doi:10.1021/jacs.7b04955

80. Ema, T.; Yokoyama, M.; Watanabe, S.; Sasaki, S.; Ota, H.; Takaishi, K. Org. Lett. 2017, 19, 4070-4073. doi:10.1021/acs.orglett.7b01838

81. Ning, R.; Ao, Y.-F.; Wang, D.-X.; Wang, Q.-Q. Chem. - Eur. J. 2018, 24, 4268-4272. doi:10.1002/chem.201800326

82. Kang, K.; Lohrman, J. A.; Nagarajan, S.; Chen, L.; Deng, P.; Shen, X.; Fu, K.; Feng, W.; Johnson, D. W.; Yuan, L. Org. Lett. 2019, 21, 652-655. doi:10.1021/acs.orglett.8b03778
83. Ning, R.; Zhou, H.; Nie, S.-X.; Ao, Y.-F.; Wang, D.-X.; Wang, Q.-Q. Angew. Chem., Int. Ed. 2020, 59, 10894-10898. doi:10.1002/anie.202003673

84. Meudtner, R. M.; Hecht, S. Angew. Chem., Int. Ed. 2008, 47, 4926-4930. doi:10.1002/anie.200800796

85. Juwarker, H.; Lenhardt, J. M.; Pham, D. M.; Craig, S. L. Angew. Chem., Int. Ed. 2008, 47, 3740-3743. doi:10.1002/anie.200800548

86. Piekarski, D. G.; Steinforth, P.; Gómez-Martínez, M.; Bamberger, J.; Ostler, F.; Schönhoff, M.; García Mancheño, O. Chem. - Eur. J. 2020, 26, 17598-17603. doi:10.1002/chem.202003994

87. García Mancheño, O.; Asmus, S.; Zurro, M.; Fischer, T. Angew. Chem., Int. Ed. 2015, 54, 8823-8827. doi:10.1002/anie.201502708

88. Zurro, M.; Asmus, S.; Bamberger, J.; Beckendorf, S.; García Mancheño, O. Chem. - Eur. J. 2016, 22, 3785-3793. doi:10.1002/chem.201504094

89. Fischer, T.; Duong, Q.-N.; García Mancheño, O. Chem. - Eur. J. 2017, 23, 5983-5987. doi:10.1002/chem.201605660

90. Duong, Q.-N.; Schifferer, L.; García Mancheño, O. Eur. J. Org. Chem. 2019, 5452-5461. doi:10.1002/ejoc.201900566

91. Gómez-Martínez, M.; Pérez-Aguilar, M. C.; Piekarski, D. G.; Daniliuc, C. G.; García Mancheño, O. Angew. Chem., Int. Ed. 2021, 60, 5102-5107. doi:10.1002/anie.202013380

92. Dorel, R.; Feringa, B. L. Angew. Chem., Int. Ed. 2020, 59, 785-789. doi:10.1002/anie.201913054

\section{License and Terms}

This is an Open Access article under the terms of the Creative Commons Attribution License (https://creativecommons.org/licenses/by/4.0). Please note that the reuse, redistribution and reproduction in particular requires that the author(s) and source are credited and that individual graphics may be subject to special legal provisions.

The license is subject to the Beilstein Journal of Organic Chemistry terms and conditions: (https://www.beilstein-journals.org/bjoc/terms)

The definitive version of this article is the electronic one which can be found at: https://doi.org/10.3762/bjoc. 17.145 